\title{
Arbuscular Mycorrhizal Fungi Improve the Antioxidative Response and the Seed Production of Suaedoideae Species Suaeda physophora Pall under Salt Stress
}

\author{
Xue YANG, Hongqing YU, Tao ZHANG*, Jixun GUO*, Xiang ZHANG
}

\author{
Institute of Grassland Science, Northeast Normal University, Key Laboratory of Vegetation Ecology, Ministry of Education, 130024 Changchun, \\ China;yangx014@nenu.edu.cn;675151661@qq.com; zhangt946@nenu.edu.cn (*corresponding author); \\ gjixun@nenu.edu.cn ('correspondingauthor); zhangx171@nenu.edu.cn
}

\begin{abstract}
Arbuscular mycorrhizal fungi (AMF) play a key role in plant growth and survival; however, the influence of AMF on the growth and production of Suaedoideae species is still not well understood. The object of this study was to understand the mechanism of AMF that affects the growth of Suaedoideae species under different saline conditions. The result showed that the Suaedoideae species Suaeda physophora was colonized by the AMF species Glomus etunicatum (Ge) and Glomus mosseae $(\mathrm{Gm})$. AMF significantly increased the activities of superoxide dismutase (SOD) and peroxidase (POD) in $S$. physophora and reduced the concentrations of malondialdehyde (MDA) and $\mathrm{H}_{2} \mathrm{O}_{2}$ in the leaves of $S$. physophora under salt stress. AMF also improved the aboveground biomass of $S$. physophora and significantly increased its seed numbers. Moreover, AMF increased the aboveground phosphorus (P) content of S. physophora. No significant difference between the effect of AMF species $G e$ and $G m$ on $S$. physophora growth was observed. These results suggest that AMF can increase the salt resistance of the Suaedoideae species $S$. physophora by increasing SOD and POD activities, reducing MDA and $\mathrm{H}_{2} \mathrm{O}_{2}$ concentrations and increasing P uptake. The results highlight that AMF might play an important role in $S$. physophora growth and population survival under harsh salt conditions.
\end{abstract}

Keywords: arbuscular mycorrhizal fungi, antioxidants, population succession, restoration, salinization

\section{Introduction}

Suaedoideae is one of the most important plant subfamilies belonging to Amaranthaceae, which is often used for vegetation recovery because many of them are high-drought tolerance, salinity resistance and tolerant to nutrient deficiency (Zhang et al., 2012), especially in some regions with saline soils. Suaeda physophora Pall belonging to the Suaedoideae subfamily is a pioneer plant in the colonization and inhabitation of saline soils and therefore plays a key role in rehabilitation and utilization of vegetation in saline-alkali land. S. physophora is an oil-seed halophyte, which produces large amounts of biomass and seeds that can be added in fodder. The seed of $S$. physophora is considered a new source of grains or vegetable oils (Wang et al., 2013). Additionally, S. physophora has high nutritional value as forage or fodder crop; therefore, it has important economic value and ecological value and is a good choice for saline agriculture in northwest China. However, the growth of $S$. physophora in field conditions is frequently not optimal and is often suppressed by salt, drought, nutrient deficiency, and so on (Song et al., 2005, 2006; Zhang et al., 2015).

Arbuscular mycorrhizal fungi (AMF), the most important functional group of the phylum Glomeromycota, is organized by their special structures, such as arbuscules and vesicles (Zhang $e t$ al., 2012). These species structures can form mutualistic associations with most land plant species and obtain carbon (C) from their plant partners in exchange for mineral nutrients (Zheng et al., 2014). AMF can not only improve plant growth but also protect their host plants from drought stress, salt stress and nutrient depletions (Morte et al., 2001; Alqarawi et al., 2014). Some plant species are unable to live without AMF in some extreme environments (Pennisi, 2004) and thus play a key role in maintaining the functionality and stability of ecosystem (Aliasgharzadeh et al., 2001; Rodriguez and Redman, 2008).

Suaedoideae species (Amaranthaceae) were typically thought of as non-AMF plant species in early studies, which had low or no infection by its unique structures, such as 
534

arbuscules or vesicles (Hirrel et al., 1978; Brundrett, 2002; Smith and Read, 2008). However, a growing number of studies have now found that many Amaranthaceae species can be colonized by AMF in Port Wakefield, South Australia (Aleman and Tiver, 2010), in Simpson Desert, Australia (O'Connor et al., 2001), and in Junggar Basin, China (Shi et al., 2006; Zhang et al., 2012), meanwhile, AMF can improve their growth. For instance, Williams et al. (1974) first observed that the growth of Atriplex canescens inoculated with Glomus mosseae increased in sterilized soil. Recently, Zhang et al. (2012) found that both in the field and in the greenhouse inoculation trials, the growth of Ceratocarpus arenarius was stimulated by the indigenous AMF community and the inoculated AMF isolates, respectively. However, the symbiotic relationship between $S$. physophora and AMF and the growth response of $S$. physophora to AMF remains unclear. The object of this study was to verify the effects of AMF on plant growth of $S$. physophora by altering the antioxidative activities and improving the phosphorus (P) uptake under a salt concentration gradient.

\section{Materials and Methods}

\section{Plant and soil conditions}

The seeds of $S$. physophora, which is considered a typical chenopod species, were collected from the salt desert in northwest China $\left(44^{\circ} 32.207^{\prime} \mathrm{N}, 87^{\circ} 16.509^{\prime} \mathrm{E}\right)$ and stored in a refrigerator at $4{ }^{\circ} \mathrm{C}$ before being used. The $S$. physophora seeds were surface disinfested in $10 \%$ (v/v) hydrogen peroxide for 10 min, rinsed three times with deionized water, and then germinated at $20^{\circ} \mathrm{C}$. After $48 \mathrm{~h}, 10$ germinated seeds were sown in pots. The seedlings were thinned to four per pot. Top soil was collected from the same site where the $S$. physophora seeds were collected. The soil was sterilized with $10 \mathrm{k} \mathrm{GyCo}{ }^{60} \gamma$ ray. The soil after sterilization had the following properties (dry matter basis): $\mathrm{pH}$ (in $\mathrm{H}_{2} \mathrm{O}$ ) 8.55; Kjeldahl-N $55.6 \mathrm{mg} \mathrm{kg}^{-1}$; organic matter $0.25 \%$; Olsen-P $\left(0.5 \mathrm{~mol} \mathrm{~L}{ }^{-1} \mathrm{NaHCO}_{3-}\right.$ extractable) $4.22 \mathrm{mg} \mathrm{kg}^{-1}$; and exchangeable $\mathrm{K}(1 \mathrm{~mol}$ $\left.\mathrm{L}^{-1} \mathrm{NH}_{4} \mathrm{OAc}\right) 175 \mathrm{mg} \mathrm{kg}^{-1}$.

\section{AMF inoculumspreparation}

Glomus etunicatum $(G e)$ and Glomus mosseae $(G m)$ were previously isolated from the rhizosphere soil of the chenopod plant $S$. physophora. The fungal isolates were cultured on white clover growing in pots in the greenhouse for 5 months by using the same soil which was collected from the field where $S$. physophora is distributed. The mycorrhizal inoculum consisted of spores, mycelium, root segments and soil. There were about 200 spores in $5 \mathrm{~g}$ soil. For the mycorrhizal treatment, $50 \mathrm{~g}$ of combined inoculums of $G e$ and $G m$ was placed into the soil, and $50 \mathrm{~g}$ of sterilized inoculum was placed into the soil for the non-mycorrhizal treatment (control). To minimize differences in the rhizosphere microbial communities of the mycorrhizal and non-mycorrhizal treatments, $10 \mathrm{ml}$ filtrates from the inoculum that were free of mycorrhizal propagules were added to the central compartment of each replicate of the nonmycorrhizal treatment, and $10 \mathrm{ml}$ deionized water was added to each of the replicates in the mycorrhizal treatments. All treatments were replicated 6 times.

\section{Experimental design}

This experiment had a completely randomized design. The main treatments included five salt concentrations: $0,50,100$, 200 and $400 \mathrm{mM}$. The salt concentrations were set according to a field survey and the results from a previous experiment (Song et al., 2005). Each salt treatment had three AMF treatments: control (C), Ge inoculation and $G m$ inoculation. The soil was watered to maintain soil water content at a level of $10 \%$ by weight. The plants were harvested after growing for four months.

\section{Mycorrbizal colonization and phosphorus content}

The shoots and roots were removed from soil and washed with deionized water. Roots were cut into $1 \mathrm{~cm}$ segments and mixed thoroughly for measuring the mycorrhizal colonization. A sub-sample of $0.5 \mathrm{~g}$ was cleared with $10 \%(\mathrm{w} / \mathrm{v}) \mathrm{KOH}$ at 90 ${ }^{\circ} \mathrm{C}$ in a water bath for $20-30 \mathrm{~min}$ and stained with $0.5 \%(\mathrm{w} / \mathrm{v})$ trypan blue. Mycorrhizal colonization was measured according to the method described by Zhang et al. (2011). The hyphal length density was measured according to the method described by Jakobsen $e t$ al. 1992. The shoots were ground and heated to dry ash in a muffle furnace at $300{ }^{\circ} \mathrm{C}$ for $3 \mathrm{~h}$ and at $550^{\circ} \mathrm{C}$ for $5 \mathrm{~h}$. The ash was dissolved in $2 \%(\mathrm{v} / \mathrm{v}) \mathrm{HCl}$. The $\mathrm{P}$ content was determined using inductively coupled plasmaatomic emission spectroscopy (ICP-AES; Perkin Elmer Optima 3300DV). Aboveground biomasses were weighed after oven dried at $65^{\circ} \mathrm{C}$ for $48 \mathrm{~h}$ in an electric constant temperature drying oven.

\section{Enzyme analysis}

For analyses of leaf superoxide dismutase (SOD), peroxidase (POD), malondialdehyde (MDA), and $\mathrm{H}_{2} \mathrm{O}_{2}$, fresh leaves from the middle of each plant were sampled after growing 8 weeks. For each replicate pot, $1 \mathrm{~g}$ of leaves was ground to a fine powder in liquid nitrogen and then homogenized in $5 \mathrm{ml}$ of extraction buffer $(50 \mathrm{mM}$ phosphate buffered saline, $\mathrm{pH} 7.8 ; 0.1 \mathrm{mM}$ EDTA; 0.3\% Triton X-100; $4 \%$ polyvinylpolypyrrolidone). After centrifugation $(10500 \times \mathrm{g}$, $4{ }^{\circ} \mathrm{C}, 20 \mathrm{~min}$ ), the supernatant was used for antioxidant enzyme analysis. The activity of SOD in leaves was quantified according to Giannopolitis and Ries (1977), one unit of the enzyme activity was defined as the amount of enzyme required to result in a $50 \%$ inhibition of the rate of nitro blue tetrazolium reduction measured at $560 \mathrm{~nm}$. POD activity in each plant was determined using the guaiacol oxidation method by Maehly and Chance (1954) in a $3 \mathrm{ml}$ reaction mixture containing $100 \mathrm{mM}$ phosphate buffer ( $\mathrm{pH}$ 6.0), 8 $\mathrm{mM}$ guaiacol, $100 \mu \mathrm{L}$ enzyme extract and $2.75 \mathrm{mM} \mathrm{H}_{2} \mathrm{O}_{2}$. The increase in absorbance was recorded at $470 \mathrm{~nm}$ within $3 \mathrm{~min}$ after enzyme extract was added. The MDA concentration was quantified according to the method described by de Azevedo Neto et al. (2006). The extract of leaves was mixed with the same volume of a thiobarbituric acid solution $(0.5 \%, \mathrm{w} / \mathrm{v})$ containing tricholoroacetic acid $(20 \%, \mathrm{w} / \mathrm{v})$. The mixture was heated at $95^{\circ} \mathrm{C}$ for $30 \mathrm{~min}$, and then cooled in an ice-bath quickly. The mixture was centrifuged at $3000 \times \mathrm{g}$ for $10 \mathrm{~min}$, and the absorbance of the supernatant was monitored at 532 and $600 \mathrm{~nm}$. The $\mathrm{H}_{2} \mathrm{O}_{2}$ concentration was determined by estimating the titanium-hydro-peroxide complex using the method described by Harinasut et al. (2003). 

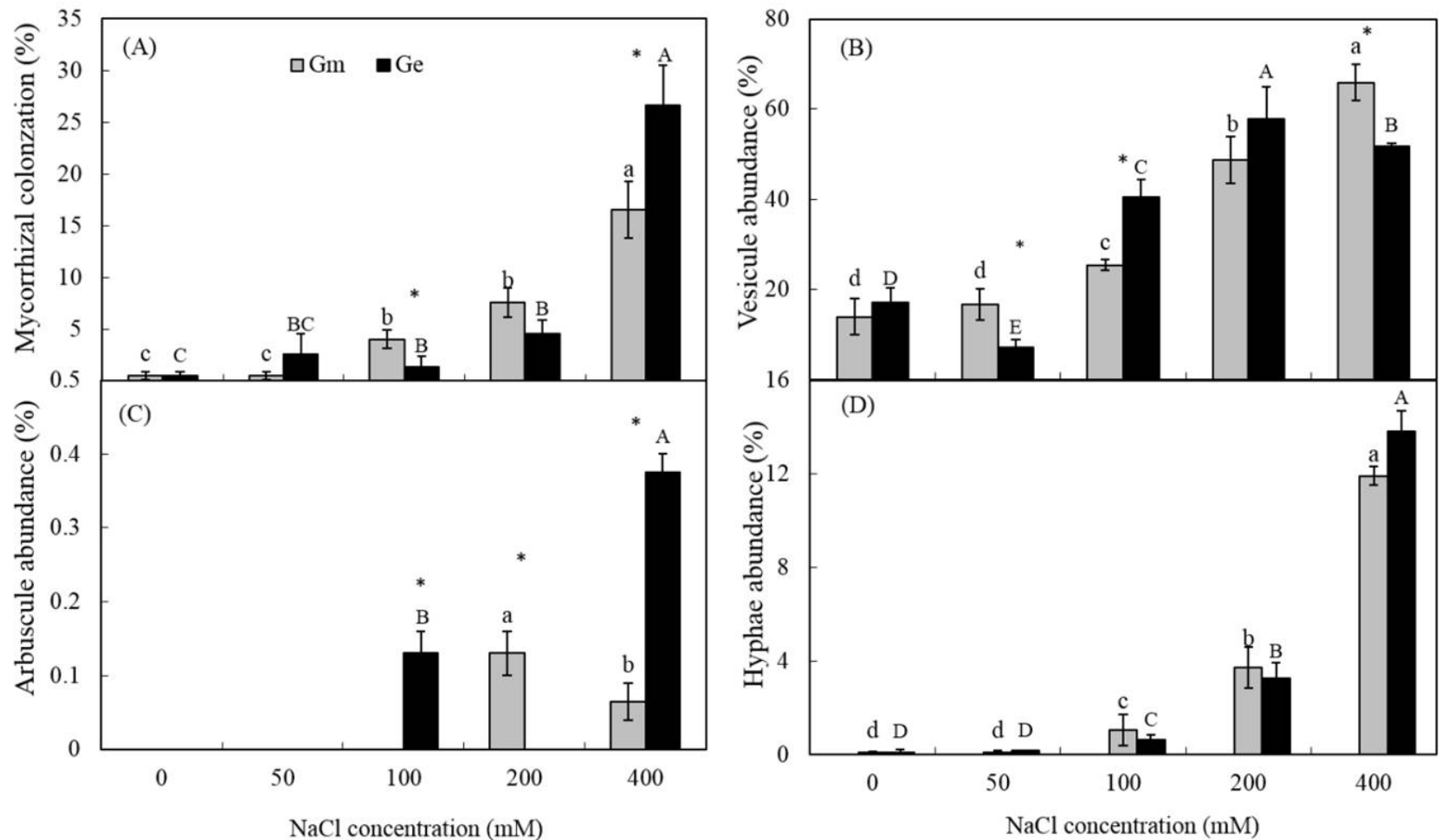

Fig. 1. Mycorrhizal colonization status in root system of $S$. physophora under different salt concentrations. Mycorrhizal colonization (A), vesicle abundance (B), arbuscule abundance (C) and hyphae abundance (D) of $G m$ or $G e$. Different lowercase letters on grey columns and capital letters on black columns indicate significant differences among different salt concentration with the same kind of AMF at 0.05 level. Asterisk represents significant difference between different AMF treatments under the same salt concentration at 0.05 level

\section{Statistical analyses}

All data were analyzed with analysis of variance (ANOVA) using SPSS software (SPSS 16.0 for Windows, Chicago, IL, USA). Differences in the means were compared among treatments with Tukey's test and were considered significant at the 0.05 level.

\section{Results}

\section{Mycorrbizal colonization}

Mycorrhizal colonization was observed in the root of $S$. physophora at different salt concentrations when the AMF were inoculated (Fig. 1A). The mycorrhizal colonization significantly increased with an increase in the salt concentration $(P<0.05)$. The mean colonization of these two AMF treatments $G m$ and $G e$ in the $400 \mathrm{mM}$ salt concentration was $174.9 \%$ higher than that in the $50 \mathrm{mM}$ salt concentration $(P<0.05)$. Significant differences in mycorrhizal colonization between inoculations of $G m$ and $G e$ were observed at the concentrations of 100 and $400 \mathrm{Mm}$ (all $P<0.05$ ), but no significant difference under other $\mathrm{NaCl}$ concentrations. The vesicule abundance in inoculation $G m$ treatment were lower than those in $G e$ treatment at concentrations of 0,100 and 200 $\mathrm{mM}$, but higher at concentrations of 50 and $400 \mathrm{mM}$ (Fig. 1B). Both arbuscule and hyphae abundances were much higher in the mycorrhizae-treated samples than the abundance of the control samples (Fig. 1C, 1D). No significant difference in

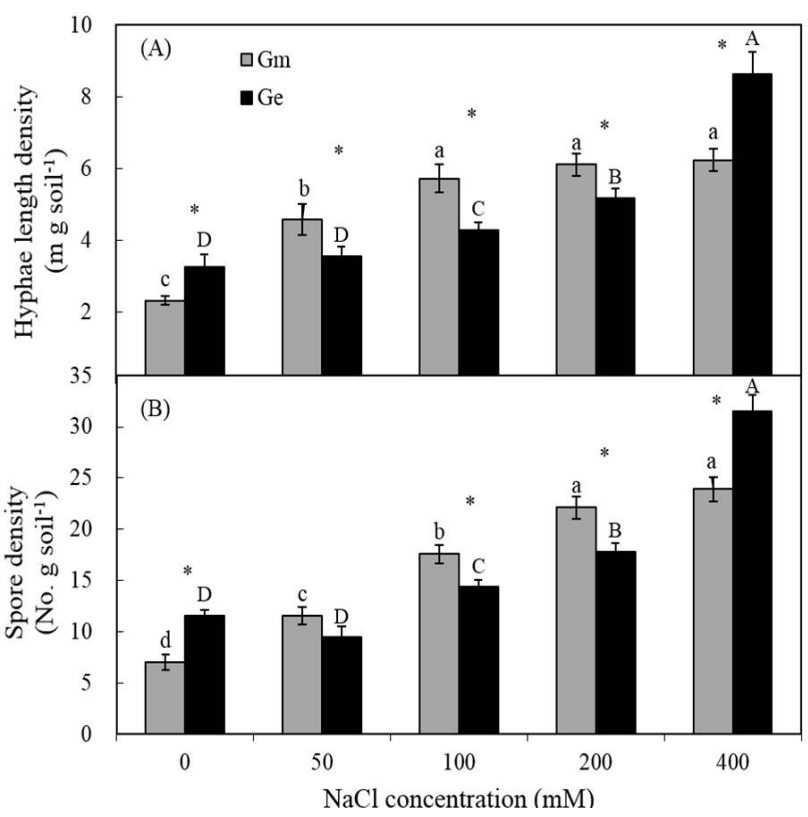

Fig. 2. The hyphae length density (A) and spore density (B) of AMF in different salt concentration. Different lowercase letters on grey columns and capital letters on black columns indicate significant differences among different salt treatment under the same inoculation AMF at 0.05 levels. Asterisk indicates significant differences between $\mathrm{Gm}$ and $\mathrm{Ge}$ treatments under same salt condition at 0.05 levels 
Table 1. Effects of AMF on activities of POD and SOD, $\mathrm{H}_{2} \mathrm{O}_{2}$ concentration and MDA concentration of $S$. physophora under different $\mathrm{NaCl}$ concentrations

\begin{tabular}{|c|c|c|c|c|c|c|c|c|c|c|c|c|}
\hline \multirow{2}{*}{$\begin{array}{l}\mathrm{NaCl} \\
(\mathrm{mM})\end{array}$} & \multicolumn{3}{|c|}{$\mathrm{POD}\left(\mathrm{U} \mathrm{g}^{-1} \mathrm{~min}^{-1}\right)$} & \multicolumn{3}{|c|}{$\operatorname{SOD}\left(\mathrm{U} \mathrm{g}^{-1} \mathrm{~min}^{-1}\right)$} & \multicolumn{3}{|c|}{$\mathrm{H}_{2} \mathrm{O}_{2}(\%)$} & \multicolumn{3}{|c|}{$\mathrm{MDA}\left(\mu \mathrm{molg}^{-1} \mathrm{DW}\right)$} \\
\hline & C & $\mathrm{Gm}$ & $\mathrm{Ge}$ & C & Gm & Ge & C & $\mathrm{Gm}$ & $\mathrm{Ge}$ & C & Gm & $\mathrm{Ge}$ \\
\hline 0 & $\begin{array}{c}96.7 \\
\pm 7.9 \mathrm{cC}\end{array}$ & $\begin{array}{c}131.9 \\
\pm 10.1 \mathrm{bC}\end{array}$ & $\begin{array}{c}198.2 \\
\pm 30.3 \mathrm{aB}\end{array}$ & $\begin{array}{c}560 \\
\pm 11.2 \mathrm{bB}\end{array}$ & $\begin{array}{c}585 \\
\pm 11.6 \mathrm{aB}\end{array}$ & $\begin{array}{c}581 \\
\pm 14.5 \mathrm{abB}\end{array}$ & $\begin{array}{c}0.22 \\
\pm 0.03 \mathrm{aA}\end{array}$ & $\begin{array}{c}0.14 \\
\pm 0.02 \mathrm{bAB}\end{array}$ & $\begin{array}{c}0.11 \\
\pm 0.02 \mathrm{bB}\end{array}$ & $\begin{array}{c}0.72 \\
\pm 0.03 \mathrm{aC}\end{array}$ & $\begin{array}{c}0.30 \\
\pm 0.02 \mathrm{bC}\end{array}$ & $\begin{array}{c}0.20 \\
\pm 0.07 \mathrm{bB}\end{array}$ \\
\hline 50 & $\begin{array}{c}132.6 \\
\pm 8.8 \mathrm{bB}\end{array}$ & $\begin{array}{c}192.6 \\
\pm 19.5 \mathrm{aAB}\end{array}$ & $\begin{array}{c}179.2 \\
\pm 8.3 \mathrm{aB}\end{array}$ & $\begin{array}{c}572 \\
\pm 14.3 \mathrm{bAB}\end{array}$ & $\begin{array}{c}615 \\
\pm 13.4 \mathrm{aA}\end{array}$ & $\begin{array}{c}605 \\
\pm 12.1 \mathrm{aAB}\end{array}$ & $\begin{array}{c}0.19 \\
\pm 0.02 \mathrm{aA}\end{array}$ & $\begin{array}{c}0.16 \\
\pm 0.01 \mathrm{bA}\end{array}$ & $\begin{array}{c}0.17 \\
\pm 0.01 \mathrm{abA}\end{array}$ & $\begin{array}{c}0.59 \\
\pm 0.06 \mathrm{aD}\end{array}$ & $\begin{array}{c}0.43 \\
\pm 0.06 \mathrm{bC}\end{array}$ & $\begin{array}{c}0.31 \\
\pm 0.05 \mathrm{cB}\end{array}$ \\
\hline 100 & $\begin{array}{c}119.3 \\
\pm 9.2 \mathrm{bB}\end{array}$ & $\begin{array}{c}191.1 \\
\pm 10.1 \mathrm{aB}\end{array}$ & $\begin{array}{c}196.8 \\
\pm 18.0 \mathrm{aB}\end{array}$ & $\begin{array}{c}590 \\
\pm 13.8 \mathrm{bAB}\end{array}$ & $\begin{array}{c}627 \\
\pm 12.6 \mathrm{aA}\end{array}$ & $\begin{array}{c}610 \\
\pm 10.3 \mathrm{abAB}\end{array}$ & $\begin{array}{c}0.21 \\
\pm 0.01 \mathrm{aA}\end{array}$ & $\begin{array}{c}0.16 \\
\pm 0.0 \mathrm{lbA}\end{array}$ & $\begin{array}{c}0.16 \\
\pm 0.01 \mathrm{bA}\end{array}$ & $\begin{array}{c}1.48 \\
\pm 0.09 \mathrm{aA}\end{array}$ & $\begin{array}{c}0.84 \\
\pm 0.10 \mathrm{bA}\end{array}$ & $\begin{array}{c}0.43 \\
\pm 0.18 \mathrm{cAB}\end{array}$ \\
\hline 200 & $\begin{array}{c}166.4 \\
\pm 9.9 \mathrm{bA}\end{array}$ & $\begin{array}{c}219.5 \\
\pm 9.3 \mathrm{aAB}\end{array}$ & $\begin{array}{c}205.6 \\
\pm 9.3 \mathrm{aB}\end{array}$ & $\begin{array}{c}608 \\
\pm 12.3 \mathrm{bA}\end{array}$ & $\begin{array}{c}638 \\
\pm 14.8 \mathrm{aA}\end{array}$ & $\begin{array}{c}627 \\
\pm 12.4 \mathrm{abA}\end{array}$ & $\begin{array}{c}0.19 \\
\pm 0.01 \mathrm{aA}\end{array}$ & $\begin{array}{c}0.16 \\
\pm 0.04 \mathrm{bA}\end{array}$ & $\begin{array}{c}0.17 \\
\pm 0.01 \mathrm{abA}\end{array}$ & $\begin{array}{c}0.65 \\
\pm 0.03 \mathrm{aD}\end{array}$ & $\begin{array}{c}0.59 \\
\pm 0.03 \mathrm{bB}\end{array}$ & $\begin{array}{c}0.54 \\
\pm 0.04 \mathrm{cA}\end{array}$ \\
\hline 400 & $\begin{array}{r}158.5 \\
\pm 14.4 \mathrm{bA} \\
\end{array}$ & $\begin{array}{r}247.5 \\
\pm 8.3 \mathrm{aA} \\
\end{array}$ & $\begin{array}{r}257.3 \\
\pm 15.6 \mathrm{aA} \\
\end{array}$ & $\begin{array}{c}612 \\
\pm 12.6 \mathrm{bA} \\
\end{array}$ & $\begin{array}{c}652 \\
\pm 15.3 \mathrm{aA} \\
\end{array}$ & $\begin{array}{c}638 \\
\pm 13.1 \mathrm{aA} \\
\end{array}$ & $\begin{array}{c}0.16 \\
\pm 0.01 \mathrm{aB} \\
\end{array}$ & $\begin{array}{c}0.13 \\
\pm 0.01 \mathrm{bB}\end{array}$ & $\begin{array}{c}0.13 \\
\pm 0.01 \mathrm{bB}\end{array}$ & $\begin{array}{c}1.06 \\
\pm 0.05 \mathrm{aB} \\
\end{array}$ & $\begin{array}{c}0.82 \\
\pm 0.07 \mathrm{bA} \\
\end{array}$ & $\begin{array}{c}0.62 \\
\pm 0.11 \mathrm{bA} \\
\end{array}$ \\
\hline
\end{tabular}

Note: Different lowercase letters in each row indicate significant differences among different AMF treatments under the same salt concentrations at 0.05 level. Different capital letters in each column indicate significant differences among different $\mathrm{NaCl}$ concentrations under same AMF treatment at 0.05 level

Table 2. Effects of AMF on aboveground biomass (A) and seed number (B) of S. physophora under different salt concentrations. Different lowercase letters indicate significant differences $(P<0.05)$ among different AMF treatments under same salt level

\begin{tabular}{|c|c|c|c|c|c|c|c|c|c|}
\hline \multirow{2}{*}{$\begin{array}{l}\mathrm{NaCl} \\
(\mathrm{mM})\end{array}$} & \multicolumn{3}{|c|}{ Aboveground biomass (g plant $\left.{ }^{-1}\right)$} & \multicolumn{3}{|c|}{ Seed number $\left(\right.$ No. plant $\left.{ }^{-1}\right)$} & \multicolumn{3}{|c|}{ Aboveground P concentration (\%) } \\
\hline & $\mathrm{C}$ & $G m$ & $G e$ & C & $G m$ & $\mathrm{Ge}$ & $\mathrm{C}$ & $G m$ & $\mathrm{Ge}$ \\
\hline 0 & $0.60 \pm 0.08 \mathrm{cC}$ & $0.80 \pm 0.10 \mathrm{bC}$ & $1.07 \pm 0.05 \mathrm{aD}$ & $10.5 \pm 1.05 \mathrm{bB}$ & $16.5 \pm 1.58 \mathrm{aD}$ & $15.8 \pm 0.97 \mathrm{aC}$ & $0.18 \pm 0.01 \mathrm{cA}$ & $0.26 \pm 0.01 \mathrm{aA}$ & $0.22 \pm 0.01 \mathrm{bA}$ \\
\hline 50 & $1.01 \pm 0.07 \mathrm{bB}$ & $1.48 \pm 0.11 \mathrm{aB}$ & $1.49 \pm 0.08 \mathrm{aC}$ & $13.5 \pm 1.67 \mathrm{bB}$ & $23.3 \pm 2.25 \mathrm{aC}$ & $20.5 \pm 2.02 \mathrm{aB}$ & $0.16 \pm 0.01 \mathrm{cB}$ & $0.22 \pm 0.01 \mathrm{aB}$ & $0.19 \pm 0.01 \mathrm{bB}$ \\
\hline 100 & $1.06 \pm 0.06 \mathrm{cB}$ & $1.55 \pm 0.06 \mathrm{aB}$ & $1.36 \pm 0.09 \mathrm{bC}$ & $18.6 \pm 1.93 \mathrm{cA}$ & $32.5 \pm 2.58 \mathrm{aB}$ & $26.9 \pm 2.44 \mathrm{aB}$ & $0.15 \pm 0.02 \mathrm{bB}$ & $0.19 \pm 0.02 \mathrm{aBC}$ & $0.18 \pm 0.01 \mathrm{aB}$ \\
\hline 200 & $1.23 \pm 0.28 \mathrm{bAB}$ & $1.94 \pm 0.19 \mathrm{aA}$ & $1.79 \pm 0.15 \mathrm{aB}$ & $21.3 \pm 2.36 \mathrm{bA}$ & $40.4 \pm 2.9 \mathrm{aA}$ & $37.9 \pm 3.89 \mathrm{aA}$ & $0.14 \pm 0.01 \mathrm{bB}$ & $0.19 \pm 0.02 \mathrm{aBC}$ & $0.18 \pm 0.01 \mathrm{aB}$ \\
\hline 400 & $1.63 \pm 0.08 \mathrm{cA}$ & $2.03 \pm 0.07 \mathrm{bA}$ & $2.38 \pm 0.05 \mathrm{aA}$ & $20.5 \pm 2.02 \mathrm{bA}$ & $46.2 \pm 4.31 \mathrm{aA}$ & $42.4 \pm 4.11 \mathrm{aA}$ & $0.13 \pm 0.01 \mathrm{bB}$ & $0.18 \pm 0.01 \mathrm{aC}$ & $0.16 \pm 0.01 \mathrm{aC}$ \\
\hline
\end{tabular}

hyphae abundance between $G m$ and $G e$ treatments under same salt concentration $(P>0.05)$ was observed, but significant difference in arbuscule abundance between $G m$ and $G e$ treatments were detected.

Spore density and hyphal length density both exhibited increased with the increase of the salt concentration (Fig. 2A, 2B). At salt concentrations of 50,100 and $200 \mathrm{mM}$, the spore density and hyphal length density in the treatments that were inoculated with $G m$ were higher $($ all $P<0.05)$ than the spore density and hyphal density in treatments that were inoculated with $G e$, and significant differences in spore density and hyphal density were observed between $G m$ and $G e$ treatments. When exposed to a salt concentration of $400 \mathrm{mM}$, the spore density and hyphal length densities in the $G e$ treatment were much higher than those of the $G m$ treatment (all $P<0.05$ ).

\section{$S O D$ and $P O D$ activities and $\mathrm{H}_{2} \mathrm{O}_{2}$ and $M D A$ in leaves}

The activities of POD and SOD in leaves significantly increased with the increase of salt concentration, both in the control and the AMF inoculation treatments (Table 1). Compared to the control, POD activities in the AMF treatments inoculated with $G m$ and $G e$ increased on average by 45.8\% $(P<0.01)$ and $53.9 \%(P<0.01)$, respectively. No significant differences were observed in POD and SOD activities between $G m$ and $G e$ treatments, except in the $0 \mathrm{mM}$ salt concentration. The presence of $G m$ and $G e$ increased SOD activities by $11.9 \%(P<0.05)$ and $4.2 \%(P>0.05)$ higher than the control of SOD activities, respectively. Although no significant differences between the SOD activities of the $G m$ and $G e$ treatments were observed, the effects of $G m$ on SOD activity were higher than the effects of $G e$.

Salinity at concentration $400 \mathrm{mM}$ decreased $\mathrm{H}_{2} \mathrm{O}_{2}$ concentration $(P<0.05$, Table 1$)$ in $S$. physophora by $32 \%$ but increased MDA concentration by $48 \%(P<0.05$, Table 1$)$, respectively, compared to control. AMF significantly decreased the $\mathrm{H}_{2} \mathrm{O}_{2}$ concentration and MDA concentration (Table 1) in plants. Compared to control, the inoculation of the AMF Gm and $G e$ decreased $\mathrm{H}_{2} \mathrm{O}_{2}$ concentrations in the plants by an average of $22.0 \%(P<0.05)$ and $24.3 \%(P<0.05)$, respectively; there were no significant differences between $G m$ and $G e$ treatments $(P>0.05)$ exposed to the same salt concentration (Table 1). The mean MDA concentration in the AMF inoculated treatments decreased by $43.5 \%(P<0.05)$ more than the MDA concentration in the control treatment (Table 1). The concentration of leaf MDA in the treatment inoculated with $G e$ was $58.5 \%(P<0.05)$ lower than the MDA concentration in the leaves in the treatment inoculated with $G m$; significant differences in the MDA concentration in leaves between the $G m$ and $G e$ treatments were detected in the same salt concentration $($ all $P<0.05)$.

\section{Aboveground biomass and seed production}

Salt stress caused significant increase in aboveground biomass of $S$. physophora. Inoculation with AMF significantly caused more improvement of the aboveground biomass of $S$. physophora exposed to the five different salt concentrations (Table 2). After exposures to salt concentrations of $100 \mathrm{mM}$ and $200 \mathrm{mM}$, the aboveground biomass of S. physophora in the treatments inoculated with $G m$ in both treatments was much higher than the biomass of $S$. physophora in the treatments inoculated with $G e$; whereas after an exposure a to salt concentration of $400 \mathrm{mM}$, the Ge-inoculated plant biomass was higher than the $G m$-inoculated $S$. physophora biomass $(P<0.05)$. The mean aboveground biomass of AMFinoculated $S$. physophora was $43.2 \%$ higher than the control biomass according to the two AMF treatments and five salt concentrations.

The inoculation of AMF also increased seed production of S. physophora (Table 2). Compared to the control, the mean seed numbers in plants in the AMF treatments increased by 79.2\% $(P<0.05)$; no significant difference between Gminoculated and $G e$-inoculated treatments were observed $(P>0.05)$. 


\section{Puptake}

The inoculation of AMF significantly increased the $\mathrm{P}$ concentration in S. physophora; the mean P concentration in treatments with AMF was $31.5 \%$ higher than the $\mathrm{P}$ concentration in the control $(P<0.05$, Table 2). After an exposure to salt concentrations of $0 \mathrm{mM}$ and $50 \mathrm{mM}$, the effect of $G m$ on the P concentration in S. physophora was higher than effect of $G e$ on the P concentration. Significant differences $(P<0.05)$ were observed between $G m$-inoculated and $G e$ inoculated treatments on the $\mathrm{P}$ concentration at these salt concentrations, whereas no significant difference between $G m$ inoculated and $G e$-inoculated treatments were observed after exposure to the other salt concentrations.

\section{Discussion}

POD and SOD are important for plants to tolerate the salinity of the soil; the former can remove intracellular oxides, and the latter can eliminate harmful substances produced by the organism during metabolic processes. Several studies found that there is a strong correlation between the enzymatic antioxidant defence system and the salt tolerance of plants (Misra et al., 2006; Tunc-Ozdemir $e$ t al., 2009). The present study found that the POD and SOD activities increased with an increase in the salt concentration. This implies that the enhancement of SOD and POD scavenge reactive oxygen species (ROS) to protect $S$. physophora from cellular oxidative damage, which is an important protective mechanism against cellular oxidative damage under salt stress (Ahmad et al., 2012). The inoculation of the AMF significantly improved the POD activity of $S$. physophora, which is consistent with previous studies on Ephedra aphylla (Alqarawi et al., 2014), tomatoes (He et al., 2007), wheat (Talaat and Shawky, 2014) and cowpeas (Abeer et al., 2015). Moreover, the AMF also increased the activity of SOD in the leaves of $S$. physophora, which corresponds with previous studies (Wu, 2011; Li et al., 2012). AMF might have some abilities to up-regulate stress to tolerance and decrease the accumulation of $\mathrm{H}_{2} \mathrm{O}_{2}$ because of the expression of various SOD genes, indicating lower oxidative damage in the colonized plants (Wu et al., 2010; Hajiboland et al., 2010). However, $\mathrm{Wu}$ (2011) found that the influence of AMF on plant salt tolerance was determined by the AMF species. In the current study, no significant differences were observed between the species $G m$ and $G e$ on the POD and SOD activities of S. physophora, which might be related to these two species of AMF both were collected from the rhizosphere soil of $S$. physophora, and they formed relatively stable associations with each other, therefore have similar effects on the POD and SOD activities of S. physophora.

MDA is a specific product of lipid peroxidation induced by ROS, and $\mathrm{H}_{2} \mathrm{O}_{2}$ is the product of cell membrane oxidation. The accumulation of MDA and $\mathrm{H}_{2} \mathrm{O}_{2}$ represents the aggravation of stress in plant and suppresses plant growth (Ahmad et al., 2010, 2012). In the present study, the MDA content increased at all $\mathrm{NaCl}$ concentrations but increased more at $\mathrm{NaCl}$ concentration of $100 \mathrm{mM}$ (Table 1). This means that salt sensitive concentration of $S$. physophora showed more lipid peroxidation at $100 \mathrm{mM}$ than other concentrations. MDA content is often used as indicators of $\mathrm{NaCl}$ stress to test the radical damage. The current results provided support for the weakest oxidative stress tolerance of $S$. physophora under salt concentration of $100 \mathrm{mM} . \mathrm{H}_{2} \mathrm{O}_{2}$ content decreased after salt treatment (Table 1), which is not accordance with the result from wheat (Zheng et al., 2009) and Catharanthus roseus (Jaleel et al., 2007), but which is consistent with results from Brassica juncea (Ahmad et al., 2012) and Suaeda salsa (Pang et al., 2005). These results revealed that salt-induced oxidative stress did not occur in the leaves of $S$. physophora. That means the activity of antioxidant enzymes (POD and SOD) increased at all $\mathrm{NaCl}$ concentrations and reduced the content of $\mathrm{H}_{2} \mathrm{O}_{2}$. $\mathrm{H}_{2} \mathrm{O}_{2}$ is harmful to growth of cells, while antioxidant enzyme catalase can decompose $\mathrm{H}_{2} \mathrm{O}_{2}$ to water and oxygen (van Breusegem et al., 2001; Ashraf, 2009), which is one of the adaptive strategy under saline stress. AMF significantly decreased the concentrations of MDA and $\mathrm{H}_{2} \mathrm{O}_{2}$ in leaves of $S$. physophora under saline conditions. These results agree with previous studies that found the AMF species $G m$ reduced the MDA concentration in Suaeda salsa leaves (Wu, 2011; Li et al., 2012) and reduced the concentration of $\mathrm{H}_{2} \mathrm{O}_{2}$ in plant leaves (Huang et al., 2008). The results suggest that the inoculation of AMF can improve plant growth via a reduction in the damage caused by MDA and $\mathrm{H}_{2} \mathrm{O}_{2}$ accumulation under salt stress. Besides that the changes of antioxidase can alter the salt tolerance of $S$. physophora, the osmotic adjustment and lateral root growth caused by inorganic ions concentration can influence the salt tolerance and improve growth (Song et al., 2006; Yuan et al., 2010). However, whether AMF can affect the osmotic and later root growth of S. physophora is still not clear under salt condition, which needs further studies.

$\mathrm{P}$ is one of the most important elements for plant growth. Generally, the accumulation of $\mathrm{P}$ plays an important role in alleviating the adverse effect of $\mathrm{P}$ deficiency on plant growth and in regulating plant growth under salt-stress (Cantrell and Linderman 2001). Because phosphate ions precipitate with $\mathrm{Ca}^{+2}, \mathrm{Mg}^{+2}$ and $\mathrm{Zn}^{+2}$ ions in saline soils and become unavailable to plants (Azcón-Aguilar et al., 1979). Therefore, P mineralization or fertilization is necessary for plant growth which may be helpful in mitigating salt stress by overcoming Pbinding capacity of the soil (Cantrell and Lindermann, 2001). A previous study found that AMF did not increase the P content of Amaranthaceae species Ceratocarpus arenarius (Zhang et al., 2012). The present study found that AMF significantly improved the aboveground $\mathrm{P}$ concentrations of $S$. physophora under different salt concentrations; this is not consistent with above previous study. The results suggest that the increase in P uptake in $S$. physophora caused by the AMF might be an important adaptation strategy to resist salt stress. Arbuscules are the main structures for the carbon (C)phosphorus trade-off between $S$. physophora and AMF, however, arbuscule abundance was not high in the root system of S. physophora, which appears to be detrimental to P uptake. The mechanism is responsible for the C-P trade-off between AMF and S. physophora need to be further studied.

AMF significantly increased aboveground biomass of $S$. physophora under different salt conditions (Table 2), which is consistent with some previous studies (Zhang et al., 2012; Alqarawi et al., 2014; Zhao et al., 2015). Moreover, the aboveground biomass of $S$. physophora increased with the increase of $\mathrm{NaCl}$ concentration in the control. The promotion of plant aboveground biomass under saline conditions may be 
538

ascribed to the growth increase of the S. physophora root system and the improved water and nutrient uptake ability, which resulted in improving plant growth and increasing aboveground biomass. However, the contributions of AMF on biomass in high salt concentrations $(200 \mathrm{mM}$ and $400 \mathrm{mM}$ ) were higher than that in control. The result suggests that AMF might play a key role in improving salt resistance of $S$. physophora under high salt condition and maintaining productivity. The possible reasons are that AMF can help plants uptake water (Porcel et al., 2003) and nutrients (Kaya et al., 2009) from the soil and can decrease the concentration of toxic ions caused by high salt in the soil (Al-Karaki et al., 2001; Mohammad et al., 2003). Moreover, AMF have been shown to increase the activities of antioxidative enzymes (He et al., 2007) and produce plant growth hormones (Iqbal and Ashraf, 2013) that have beneficial effects on plant growth under salt stress.

It is well known that the seedlings of Amaranthaceae species in saline areas must resist the impact of the harsh environment, such as drought, waterlogging, and high salt (Song et al., 2005; Wang et al., 2008; Zhang et al., 2015). The number of seed germinated in the field is usually very high, but most of them cannot survive; therefore, a certain number of seeds is needed to ensure the reproduction of the next generation's population (Wang et al., 2008). In the present study, the seed number of $S$. physophoraincreased under salt treatment (Fig. 4B), which might be an adaptive strategy of salt stress. High salinity could suppress germination of Amaranthaceae species (Wang et al. 2015), more seeds can reduce the risk of inhibition of seed germination caused by salinity inhibiting and help species survive in high salt environments. AMF significantly increased the number of seeds produced by $S$. physophora, which indicates that AMF play an important role in seed production, which can ensure the reproduction of the S. physophora population in the future. Moreover, an increase in seed production will increase the amount of oil produced from $S$. physophora seeds.

\section{Conclusions}

The current result found that the Suaedoideae species $S$. physophora was colonized by AMF. AMF significantly reduced the negative effect of salt on the growth of $S$. physophora via increasing the activities of SOD and POD and reducing the contents of $\mathrm{H}_{2} \mathrm{O}_{2}$ and MDA. AMF significantly increased aboveground $\mathrm{P}$ content, biomass and seeds number. Moreover, the contributions of AMF on the aboveground biomass and seed number in high $\mathrm{NaCl}$ concentrations were much higher than in control or low $\mathrm{NaCl}$ concentration. These results suggest that AMF can reduce the negative effects of salt on the growth of Suaedoideae species and maintain the productivity and population reproduction, especially in high salt conditions. The present results highlight that AMF might be as a potential approach which can be used to restore Suaedoideae species in saline region.

\section{Acknowledgements}

This work was funded by the National Natural Science Foundation of China, grant number 31300097 and 31470405. The authors have no conflict of interests to declare.

\section{References}

Abeer H, Abd_Allah EF, Alqarawi AA, Egamberdieva D (2015). Induction of salt stress tolerance in cowpea Vigna unguiculata (L.) Walp. by arbuscular mycorrhizal fungi. Legume Research 38(5):579-588.

Ahmad MSA, Ashraf M, Ali Q (2010). Soil salinity as a selection pressure is a key determinant for the evolution of salt tolerance in blue panicgrass (Panicum antidotale Retz.). Flora 205:37-45.

Ahmad P, Hakeem KR, Kumar A, Ashraf M, Akram NA (2012). Saltinduced changes in photosynthetic activity and oxidative defense system of three cultivars of mustard (Brassica juncea L.). African Journal of Biotechnology 11:26942703.

Al-Karaki GN, Hammad R, Rusan M (2001). Response of two tomato cultivars differing in salt tolerance to inoculation with mycorrhizal fungi under salt stress. Mycorrhiza 11:43-47.

Aleman R, Tiver F (2010). Endomycorrhizal infection levels among chenopod plant species at Port Wakefield, South Australia. Transactions of the Royal Society of South Australia 134(1):1-4.

Aliasgharzadeh N, Rastin SN, Towfighi H, Alizadeh A (2001). Occurrence of arbuscular mycorrhizal fungi in saline soils of the Tabriz Plain of Iran in relation to some physical and chemical properties of soil. Mycorrhiza 11(3):119-122.

Alqarawi AA, Abd_Allah EF, Hashem A (2014). Alleviation of saltinduced adverse impact via mycorrhizal fungi in Ephedra aphylla Forsk. Journal of Plant Interaction 9:802-810.

Ashraf M (2009). Biotechnological approach of improving plant salt tolerance using antioxidants as markers. Biotechnology Advances 27:84-93.

Azco'n-Aguilar C, Azco'n R, BareaJM (1979). Endomycorrhizal fungi andrhizobium as biological fertilizers for Medicago sativa in normal cultivation. Nature 279:325-327.

Brundrett MC (2002). Coevolution of roots and mycorrhizas of land plants. New Phytologist 154(2):275-304.

Cantrell IC, Linderman RG (2001). Preinoculation of lettuce and onion with VA mycorrhizal fungi reduces deleterious effects of soil salinity. Plant and Soil 233(2):269-281.

De Azevedo Neto AD, Prisco JT, Enéas-Filho J, de Abreu CEB, Gomes-Filho E (2006). Effect of salt stress on antioxidative enzymes and lipid peroxidation in leaves and roots of salt-tolerant and saltsensitive maize genotypes. Environmental and Experimental Botany 56:87-94.

Giannopolitis CN, Ries SK (1977). Superoxide dismutase: I. occurrence in higher plants. Plant Physiology 59:309-314.

Harinasut P, Poonsopa D, Roengmongkol K, Charoensataporn R (2003). Salinity effects on antioxidant enzymes in mulberry cultivar. Science Asia 29:109-113.

Hajiboland R, Aliasgharzadeh N, Laiegh SF, Poschenrieder C (2010). Colonization with arbuscular mycorrhizal fungi improves salinity tolerance of tomato (Solanum lycopersicon L.) plants. Plant and Soil 331:313-327.

He Z, He C, Zhang Z, Zou Z, Wang H (2007). Changes of antioxidative enzymes and cell membrane osmosis in tomato 
colonized by arbuscular mycorrhizae under $\mathrm{NaCl}$ stress. Colloids and Surfaces B-Biointerfaces 59(2):128-133.

Hirrel MC, Mehravaran H, Gerdemann JW (1978). Vesiculararbuscular mycorrhizae in the Chenopodiaceae and Cruciferae: do they occur? Canadian Journal of Botany-Revue Canadienne de Botanique 56:2813-2817.

Huang LL, Yang C, Zhao Y, Xu X, Xu Q, Li GZ (2008). Antioxidant defenses of mycorrhizal fungus infection against $\mathrm{SO}_{2}$-induced oxidative stress in Avenanuda seedlings. Bulletin of Environmental Contamination and Toxicology 81(5):440-444.

Iqbal M, Ashraf M (2013). Alleviation of salinity-induced perturbations in ionic and hormonal concentrations in spring wheat through seed preconditioning in synthetic auxins. Acta Physiologiae Plantarum 35:1093-1112.

Jaleel CA, Gopi R, Sankar B, Manivannan P, Kishorekumar A,Sridharan R, Panneerselvam R (2007). Studies on germination, seedling vigour, lipid peroxidation and proline metabolism in Catharanthus roseus seedlings under salt stress. South African Journal of Botany 73:190-195.

Jakobsen I, Abbott LK, Robson AD (1992). External hyphae of vesicular-arbuscular mycorrhizal fungi associated with Trifolium subterraneum L. 2. Hyphal transport of ${ }^{32} \mathrm{P}$ over defined distances. New Phytologist 120(4):509-516.

Kaya C, Ashraf M, Sonmez O, Aydemir S, Tuna AL, Cullu MA (2009). The influence of arbuscular mycorrhizal colonisation on key growth parameters and fruit yield of pepper plants grown at high salinity. Scientia Horticulturae 121(1):1-6.

Li T, Liu RJ, He XH, Wang BS (2012). Enhancement of superoxide dismutase and catalase activities and salt tolerance of euhalophyte Suaeda salsa L. by mycorrhizal fungus Glomus mosseae. Pedosphere 22(2):217-224.

Maechlay A, Chance B (1954). The assay of catalase and peroxidase. Methods of Biochemical Analysis. Interscience Inc., New York pp 357-424.

Misra A, Latowski D, Strzalka K (2006). The xanthophyll cycle activity in kidney bean and cabbage leaves under salinity stress. Russian Journal of Plant Physiology 53(1):102-109.

Mohammad MJ, Malkawi HI, Shibli R (2003). Effects of arbuscular mycorrhizal fungi and phosphorus fertilization on growth and nutrient uptake of barley grown on soils with different levels of salts. Journal of Plant Nutrition 26(1):125-137.

Morte A, Díaz G, Rodríguez P, AlarcónJJ, Sánchez-Blanco MJ (2001). Growth and water relations in mycorrhizal and nonmycorrhizal Pinus halepensis plants in response to drought. Biologia Plantarum 44:263-267.

O'Connor PJ, Smith SE, Smith FA (2001). Arbuscular mycorrhizal associations in the southern Simpson Desert. Australian Journal of Botany 49:493-499.

Pang CH, Zhang SJ, Gong ZZ, Wang BS (2005). NaCl treatment markedly enhances $\mathrm{H}_{2} \mathrm{O}_{2}$-scavenging system in leaves of halophyte Suaeda salsa. Physiologia Plantarum 125:490-499.

Pennisi E (2004). The secret life of fungi. Science 304:1620-1622.
Porcel R, Barea JM, Ruiz-Lozano JM (2003). Antioxidant activities in mycorrhizal soybean plants under drought stress and their possible relationship to the process of nodule senescence. New Phytologist 157(1):135-143.

Rodriguez R, Redman R (2008). More than 400 million years of evolution and some plants still can't make it on their own: plant stress tolerance via fungal symbiosis. Journal of Experimental Botany 59:1109-1114.

ShiZY, Feng G, Christie P, Li XL (2006). Arbuscular mycorrhizal status of spring ephemerals in the desert ecosystem of Junggar Basin, China. Mycorrhizal 16(4):269-275.

Smith SE, Read DJ (2008). Mycorrhizal symbiosis. Academic Press (3rd ed), Boston.

Song J, Feng G, Tian C, Zhang F (2005). Strategies for adaptation of Suaeda physophora, Haloxylon ammodendron and Haloxylon persicum to a saline environment during seed-germination stage. Annual of Botany 96:399-405.

Song J, Feng G, Tian CY, Zhang FS (2006). Osmotic adjustment traits of Suaeda physophora, Haloxylon ammodendron and Haloxylon persicum in field or controlled conditions. Plant Science 170(1):113119.

Talaat NB, Shawky BT (2014). Modulation of the ROS-scavenging system in salt-stressed wheat plants inoculated with arbuscular mycorrhizal fungi. Journal of Plant Nutrition and Soil Science 177(2):199-207.

Tunc-Ozdemir M, Miller G, Song L, Kim J, Sodek A, Koussevitzky S (2009). Thiamin confers enhanced tolerance to oxidative stress in Arabidopsis. Plant Physiology 151:421-432.

Van Breusegem F, Vranová E, Dat JF, Inzé D (2001). The role of active oxygen species in plant signal transduction. Plant Sciences 161:405414.

Wang FX, Xu YG, Wang S, Shi WW, Liu RR, Feng G, SongJ (2015). Salinity affects production and salt tolerance of dimorphic seeds of Suaeda salsa. Plant Physiology and Biochemistry 95:41-48.

Wang L, Huang Z, Baskin C, Baskin J, Dong M (2008). Germination of dimorphic seeds of the desert annual halophyte Suaeda aralocaspica (Chenopodiaceae), a C4 plant without Kranz anatomy. Annual of Botany 102:757-769.

Wang L, Zhao ZY, Zhang K, Tian CY (2013). Reclamation and utilization of saline soils in arid northwestern China: A promising halophyte drip-irrigation system. Environmental Science \& Technology 47:5518-5519.

Williams SE, Wollum AG, AldonEF (1974). Growth of Atriplex canescens (Pursh) Nutt. improved by formation of vesiculararbuscular mycorrhizae. Soil Science Society of America Journal 38:962-965.

Wu QS, Zou YN, Liu W, Ye XF, Zai HF, Zhao LJ (2010). Alleviation of salt stress in citrus seedlings inoculated with mycorrhiza: changes in leaf antioxidant defense systems. Plant Soil and Environment 56:470-475.

Wu QS (2011). Mycorrhizal efficacy of trifoliate orange seedlings on alleviating temperature stress. Plant Soil Environment 57(10):459464. 
Zhao WW, Fu TT, Wang FX, Xu YG, Song J (2015). The adaptation of Suaeda physophora seedlings to salinity and drought environments. International Conference on Industrial Technology and Management Science 2015 Conference. Tianjin pp 249-252.

Zheng CF, Jiang D, Liu FL, Dai TB, Liu WC, Jing Q, Cao WX (2009). Exogenous nitric oxide improves seed germination in wheat against mitochondrial oxidative damage induced by high salinity. Environmental and Experimental Botany 67:222-227.

Zheng Y, Kim YC, Tian XF, Chen L, Yang W, Gao C (2014). Differential responses of arbuscular mycorrhizal fungi to nitrogen addition in a near pristine Tibetan alpine meadow. FEMS Microbiology Ecology 89:594-605. response of a desert ephemeral plant, Plantago minuta, to indigenous arbuscular mycorrhizal fungi in a central Asia Desert. Symbiosis 55(2):77-84. 